\title{
FLUXAPYROXAD IN THE ASIAN SOYBEAN RUST CONTROL IN THE CERRADO BIOME ${ }^{1}$
}

\author{
RAFAEL MENEZES SILVA DE FREITAS ${ }^{2}$, LEONEL ESPÓSITO DE LIMA ${ }^{3}$, ROGER SANTOS SILVA ${ }^{2}$, HERCULES \\ DINIZ CAMPOS ${ }^{2}$, ADRIANO PERIN ${ }^{3 *}$
}

\begin{abstract}
The etiologic agent of the Asian soybean rust is the Phakopsora pachyrhizi, which causes a reduction in the photosynthetic leaf area and, consequently, in the crop yield. Chemical control is one of the main measures for its management. The objective of this work was to evaluate the efficacy and selectivity of the fluxapyroxad fungicide on controlling the Asian soybean rust, under the edaphoclimatic conditions of the Cerrado biome. The experiment was conducted in an area under no-tillage system, in the Agricultural Research Center, Rio Verde, Goias, Brazil, during the 2012/2013 crop season, using the cultivar NA7337. A randomized block experimental design was used, with twelve treatments and four replications. The treatments consisted of applications of fluxapyroxad (FX), pyraclostrobin (PT), epoxiconazole (EX) and metconazole (MZ). The average severity of the disease in the plants reached $37 \%$ in the Control. All treatments with fungicides differed from the Control. Treatments 9, 10, 11 and 12 provided the greatest rates of soybean rust control. The treatments 10, 11 and 12 had the highest thousand grain weights, and the yields of the treatments 2, 3 and 11 , despite higher than the Control, were lower than the treatments 4, 5, 6, 7, 8, 9, 10 and 12, which had statistically equal yields. The increasing in yield, compared to the Control, ranged from $10.05 \%$ (pyraclostrobin, epoxiconazole + pyraclostrobin + mineral oil) to $30.55 \%$ (pyraclostrobin, pyraclostrobin + fluxapyroxad + mineral oil and pyraclostrobin + metconazole + mineral oil). The highest rates of soybean rust control were presented by fungicides containing fluxapyroxad.
\end{abstract}

Keywords: Glycine max. Phakopsora pachyrhizi. Chemical control. Carboxamide.

\section{FLUXAPIROXADE NO CONTROLE DA FERRUGEM ASIÁTICA DA SOJA EM CONDIÇÕES DE CERRADO}

RESUMO - A ferrugem asiática da soja, cujo agente etiológico é o fungo Phakopsora pachyrhizi, causa redução da área foliar fotossintética e diminui a produtividade da cultura, sendo o controle químico uma das principais medidas no seu manejo. O objetivo do trabalho foi avaliar a eficácia e a seletividade do fungicida fluxapiroxade no controle da ferrugem asiática na cultura da soja, em condições edafoclimáticas do Cerrado. $\mathrm{O}$ experimento foi conduzido em área sob sistema de plantio direto, no Centro de Pesquisa Agrícola, Rio Verde, Goiás, durante a safra 2012/2013, utilizando a cultivar NA 7337. O delineamento experimental utilizado foi blocos ao acaso, com doze tratamentos e quatro repetições. Os tratamentos consistiram de aplicação de fluxapiroxade (FX), piraclostrobina (PT), epoxiconazol (EX) e metconazol (MZ). A severidade média da doença nas plantas chegou a $37 \%$ na testemunha. Todos os tratamentos contendo fungicidas diferiram da testemunha. Os tratamentos 9, 10, 11 e 12 foram os que proporcionaram maiores níveis de controle da ferrugem asiática, os tratamentos 10, 11 e 12 alcançaram maiores massa de mil grãos e os tratamentos 2, 3 e 11 foram mais produtivos que a testemunha, porém inferiores aos $4,5,6,7,8,9,10$ e 12, sendo estes estatisticamente iguais. $\mathrm{O}$ incremento de produtividade em relação à testemunha variou de 10,05\% (piraclostrobina, epoxiconazol + piraclostrobina + óleo mineral) a 30,55\% (piraclostrobina, piraclostrobina + fluxapiroxade + óleo mineral, piraclostrobina + metconazol + óleo mineral). Os maiores níveis de controle foram evidenciados nos fungicidas contendo fluxapiroxade.

Palavras-chave: Glycine max. Phakopsora pachyrhizi. Controle químico. Carboxamida.

\footnotetext{
*Corresponding author

${ }^{1}$ Received for publication in $04 / 24 / 2015$; accepted in $02 / 03 / 2016$.

Final undergraduate dissertation of the first author.

${ }^{2}$ Laboratory of Plant Pathology, Universidade de Rio Verde, Rio Verde, GO, Brazil; rafaelmsdf@gmail.com; rogersantos.agro@hotmail.com; camposhd@brturbo.com.br.

${ }^{3}$ Laboratório of Plant Science, Instituto Federal Goiano - campus Rio Verde, Rio Verde, GO, Brazil; leonel.agronomy@gmail.com, adriano.perin@ifgoiano.edu.br.
} 


\section{INTRODUCTION}

The soybean stood out in the Brazilian agribusiness exports, reaching US \$ 33.8 billion from August 2013 to July 2014, an increase of $19.6 \%$ over the same period last year, despite the reduction in the average price, the volume exported increased by $24.4 \%$ (CONAB, 2014). The increase in crop area and monoculture contributed to the increase of diseases such as soybean rust, which has as etiological agent the Phakopsora pachyrhizi Syd. \& P. Syd. This pathogen is commonly found in the main producing areas of soybean and, if not controlled, may cause yield losses, which are estimated in approximately $80 \%$ under optimal conditions for the fungus development, due to the rapid yellowing and premature defoliation, which hinder the formation of pods and beans (SOARES et al., 2004; YORINORI et al., 2005). Initial symptoms of soybean rust consist of small leaf spots of brown to dark brown color (PINTO, 2011). The fungus $P$. pachyrhizi penetration is predominantly in the epidermal junction, forming the appressorium (MAGNANI 2007). After infection, injury and uredospore pustules may appear within 7 to 8 days (IGARASHI et al., 2014), thus having a short life cycle, indicating a rapid disease spread (BONDE et al., 2007).

The interaction between seed and shoot treatments have been assessed, relating some epidemic components, such as the time of appearance of symptoms, initial intensity, progress rate and final quantity (MENEGON et al., 2005). Despite the efforts in plant breeding to find resistant sources to this pathogen, the obtaining of resistant cultivars is hindered by the high variability of $P$. pachyrhizi, which is able to develop new pathogenic races and overcome the resistance of new varieties (BARBOSA, 2014).

The use of fungicides has been collaborating with the management of the Asian soybean rust when applied at appropriate times. Levy (2005) evaluating fungicide applications on soybeans, reported that the plants need to be protected against infection in all reproductive stages to avoid yield loss. The information on efficacy, interval time and number of applications are very important for the management of chemicals, considering the aggressiveness of this disease and the absence of resistant cultivars (FURLAN, 2013).

The use of fungicide is, nowadays, the most important tool to control this fungus, preventing low yields and losses to the farmers (GARCÉSFIALLOS, 2011). However, excluding fungicides that were once effective but lost their ability to inactivate this pathogen. According to Cunha et al. (2014), the difficulty in controlling the P. pachyrhizi remained, partly because of the mode of application of these products. Thus, the adoption of effective fungicides, and correct application modes for controlling of this disease is essential.

Thus, the objective of this work was to evaluate the efficacy and selectivity of the fluxapyroxad fungicide in controlling the Asian rust on soybeans under the edaphoclimatic conditions of the Cerrado biome.

\section{MATERIAL AND METHODS}

The experiment was conducted in an area under no-tillage system $\left(17^{\circ} 47^{\prime} 020^{\prime \prime} \mathrm{S}, 50^{\circ} 59^{\prime} 830^{\prime \prime} \mathrm{O}\right.$ and $742 \mathrm{~m}$ of altitude), in the Agricultural Research Center, Rio Verde, Goias, Brazil, during the 2012/2013 crop season. The area had been cultivated with soybean in the previous summer (2011/2012 crop season) followed by sorghum as second crop.

Planting was performed at December 18, 2012, with seeds inoculated with Nitragin Optimize ${ }^{\circledR}$ at the concentration recommended by the manufacturer. The cultivar used was the NA7337RR, which has medium cycle (115-120 days). The plants were arranged in eight rows of five meters in length, and the plot consisted of the four central rows, discarding $50 \mathrm{~cm}$ from each end of the rows, therefore, the plot area had $8 \mathrm{~m}^{2}$, as recommended by the Plant Pathology Commission during the XXVIII Soybean Research Meeting for the Brazilian Central Region (EMBRAPA, 2006). Twenty plants per meter were maintained, spaced $50 \mathrm{~cm}$ between rows, with a final population of 460000 plants $\mathrm{ha}^{-1}$. Fertilization was performed according to the soil analysis, adding $200 \mathrm{~kg} \mathrm{ha}^{-1}$ of $02-20-20$ (N:P:K) before and after planting. Cultural practices were the same performed in a commercial farm. Herbicides and insecticides were used as needed. Environmental conditions during the experiments were extremely important for the occurrence and development of this disease. The average precipitation and temperature from October to March favored the incidence and severity of Asian rust on soybean plants (Figure 1). 


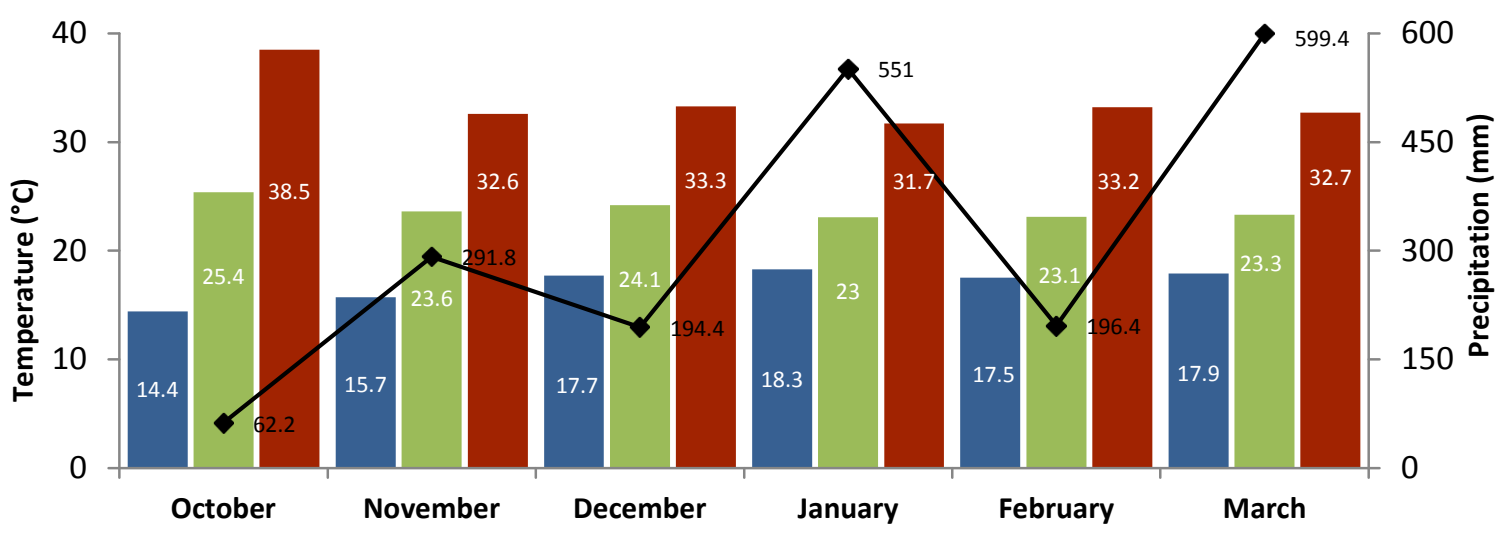

Minimum Temperature Mean Temperature

Maximum Temperature

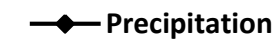

Figure 1. Mean monthly precipitation $(\mathrm{mm})$ and temperature $\left({ }^{\circ} \mathrm{C}\right)$ during the experimental period (October 2012 to March 2013).

The treatments consisted of a Control, without fungicide application and fungicide applications with pyraclostrobin, pyraclostrobin + epoxiconazole, pyraclostrobin + metconazole, fluxapyroxad + pyraclostrobin, and pyraclostrobin + epoxiconazole + fluxapyroxad. The fungicides, rates, application times and phenological stage at each application are shown in Table 1 .

Table 1. Treatments used for Asian soybean rust control.

\begin{tabular}{|c|c|c|c|}
\hline & Treatments & $\begin{array}{c}\text { Rates* } \\
\text { (mL c. p. } \\
\text { or f. p. ha }{ }^{-1} \text { ) }\end{array}$ & $\begin{array}{l}\text { Application } \\
\text { Time }\end{array}$ \\
\hline 1 & Control & - & - \\
\hline \multirow{4}{*}{2} & (pyraclostrobin $25 \% \mathrm{~m} / \mathrm{v}$ ) & $(300)$ & V6 \\
\hline & $($ pyraclostrobin $13.3 \% \mathrm{~m} / \mathrm{v}+$ epoxiconazole $5 \% \mathrm{~m} / \mathrm{v})+($ mineral oil $75.6 \% \mathrm{~m} / \mathrm{v})$ & $(500)+(500)$ & $\mathrm{R} 1$ \\
\hline & $($ pyraclostrobin $13.3 \% \mathrm{~m} / \mathrm{v}+$ epoxiconazole $5 \% \mathrm{~m} / \mathrm{v})+($ mineral oil $75.6 \% \mathrm{~m} / \mathrm{v})$ & $(500)+(500)$ & R5.1 \\
\hline & $($ pyraclostrobin $13.3 \% \mathrm{~m} / \mathrm{v}+$ epoxiconazole $5 \% \mathrm{~m} / \mathrm{v})+($ mineral oil $75.6 \% \mathrm{~m} / \mathrm{v})$ & $(500)+(500)$ & R5.4 \\
\hline \multirow{4}{*}{3} & $($ pyraclostrobin $13.3 \% \mathrm{~m} / \mathrm{v}+$ epoxiconazole $5 \% \mathrm{~m} / \mathrm{v})+($ mineral oil $75.6 \% \mathrm{~m} / \mathrm{v})$ & $(500)+(500)$ & V6 \\
\hline & $($ pyraclostrobin $13.3 \% \mathrm{~m} / \mathrm{v}+$ epoxiconazole $5 \% \mathrm{~m} / \mathrm{v})+($ mineral oil $75.6 \% \mathrm{~m} / \mathrm{v})$ & $(500)+(500)$ & $\mathrm{R} 1$ \\
\hline & $($ pyraclostrobin $13.3 \% \mathrm{~m} / \mathrm{v}+$ epoxiconazole $5 \% \mathrm{~m} / \mathrm{v})+($ mineral oil $75.6 \% \mathrm{~m} / \mathrm{v})$ & $(500)+(500)$ & R5.1 \\
\hline & $($ pyraclostrobin $13.3 \% \mathrm{~m} / \mathrm{v}+$ epoxiconazole $5 \% \mathrm{~m} / \mathrm{v})+($ mineral oil $75.6 \% \mathrm{~m} / \mathrm{v})$ & $(500)+(500)$ & R5.4 \\
\hline \multirow{4}{*}{4} & (pyraclostrobin $25 \% \mathrm{~m} / \mathrm{v})$ & $(300)$ & V6 \\
\hline & $($ fluxapyroxad $16.7 \% \mathrm{~m} / \mathrm{v}+$ pyraclostrobin $33.3 \% \mathrm{~m} / \mathrm{v})+($ mineral oil $75.6 \% \mathrm{~m} / \mathrm{v})$ & $(300)+(500)$ & $\mathrm{R} 1$ \\
\hline & $($ pyraclostrobin $13.3 \% \mathrm{~m} / \mathrm{v}+$ epoxiconazole $5 \% \mathrm{~m} / \mathrm{v})+($ mineral oil $75.6 \% \mathrm{~m} / \mathrm{v})$ & $(500)+(500)$ & R5.1 \\
\hline & $($ pyraclostrobin $13.3 \% \mathrm{~m} / \mathrm{v}+$ epoxiconazole $5 \% \mathrm{~m} / \mathrm{v})+($ mineral oil $75.6 \% \mathrm{~m} / \mathrm{v})$ & $(500)+(500)$ & R5.4 \\
\hline \multirow{4}{*}{5} & (pyraclostrobin $13.3 \% \mathrm{~m} / \mathrm{v}+$ epoxiconazole $5 \% \mathrm{~m} / \mathrm{v}$ ) & $(500)$ & V6 \\
\hline & $($ fluxapyroxad $16.7 \% \mathrm{~m} / \mathrm{v}+$ pyraclostrobin $33.3 \% \mathrm{~m} / \mathrm{v})+($ mineral oil $75.6 \% \mathrm{~m} / \mathrm{v})$ & $(300)+(500)$ & R1 \\
\hline & $($ pyraclostrobin $13.3 \% \mathrm{~m} / \mathrm{v}+$ epoxiconazole $5 \% \mathrm{~m} / \mathrm{v})+($ mineral oil $75.6 \% \mathrm{~m} / \mathrm{v})$ & $(500)+(500)$ & R5.1 \\
\hline & (pyraclostrobin $13.3 \% \mathrm{~m} / \mathrm{v}+$ epoxiconazole $5 \% \mathrm{~m} / \mathrm{v})+($ mineral oil $75.6 \% \mathrm{~m} / \mathrm{v})$ & $(500)+(500)$ & R5.4 \\
\hline \multirow{4}{*}{6} & $($ pyraclostrobin $25 \% \mathrm{~m} / \mathrm{v})$ & $(500)$ & V6 \\
\hline & $($ fluxapyroxad $16.7 \% \mathrm{~m} / \mathrm{v}+$ pyraclostrobin $33.3 \% \mathrm{~m} / \mathrm{v})+($ mineral oil $75.6 \% \mathrm{~m} / \mathrm{v})$ & $(300)+(500)$ & R1 \\
\hline & $($ fluxapyroxad $16.7 \% \mathrm{~m} / \mathrm{v}+$ pyraclostrobin $33.3 \% \mathrm{~m} / \mathrm{v})+($ mineral oil $75.6 \% \mathrm{~m} / \mathrm{v})$ & $(300)+(500)$ & R5.1 \\
\hline & $($ pyraclostrobin $13.3 \% \mathrm{~m} / \mathrm{v}+$ epoxiconazole $5 \% \mathrm{~m} / \mathrm{v})+($ mineral oil $75.6 \% \mathrm{~m} / \mathrm{v})$ & $(500)+(500)$ & R5.4 \\
\hline \multirow{4}{*}{7} & (pyraclostrobin $13.3 \% \mathrm{~m} / \mathrm{v}+$ epoxiconazole $5 \% \mathrm{~m} / \mathrm{v}$ ) & $(500)$ & V6 \\
\hline & $($ fluxapyroxad $16.7 \% \mathrm{~m} / \mathrm{v}+$ pyraclostrobin $33.3 \% \mathrm{~m} / \mathrm{v})+($ mineral oil $75.6 \% \mathrm{~m} / \mathrm{v})$ & $(300)+(500)$ & $\mathrm{R} 1$ \\
\hline & $($ fluxapyroxad $16.7 \% \mathrm{~m} / \mathrm{v}+$ pyraclostrobin $33.3 \% \mathrm{~m} / \mathrm{v})+($ mineral oil $75.6 \% \mathrm{~m} / \mathrm{v})$ & $(300)+(500)$ & R5.1 \\
\hline & $($ pyraclostrobin $13.3 \% \mathrm{~m} / \mathrm{v}+$ epoxiconazole $5 \% \mathrm{~m} / \mathrm{v})+($ mineral oil $75.6 \% \mathrm{~m} / \mathrm{v})$ & $(500)+(500)$ & R5.4 \\
\hline \multirow{4}{*}{8} & (pyraclostrobin $25 \% \mathrm{~m} / \mathrm{v})$ & $(300)$ & V6 \\
\hline & (fluxapyroxad $16.7 \% \mathrm{~m} / \mathrm{v}+$ pyraclostrobin $33.3 \% \mathrm{~m} / \mathrm{v})+($ mineral oil $75.6 \% \mathrm{~m} / \mathrm{v})$ & $(300)+(500)$ & R1 \\
\hline & (fluxapyroxad $16.7 \% \mathrm{~m} / \mathrm{v}+$ pyraclostrobin $33.3 \% \mathrm{~m} / \mathrm{v})+($ mineral oil $75.6 \% \mathrm{~m} / \mathrm{v})$ & $(300)+(500)$ & R5.1 \\
\hline & $($ pyraclostrobin $13 \% \mathrm{~m} / \mathrm{v}+$ metconazole $8 \% \mathrm{~m} / \mathrm{v})+($ mineral oil $75.6 \% \mathrm{~m} / \mathrm{v})$ & $(500)+(500)$ & R5.4 \\
\hline
\end{tabular}

*mL of the commercial product or formulated product per hectare. 
Table 1. Continuation.

\begin{tabular}{|c|c|c|c|}
\hline & Treatments & $\begin{array}{c}\text { Rates* } \\
\text { (mL c. p. } \\
\text { or f. p. ha } \text { ha }^{-1} \text { ) }\end{array}$ & $\begin{array}{l}\text { Application } \\
\text { Time }\end{array}$ \\
\hline \multirow{4}{*}{9} & (pyraclostrobin $13.3 \% \mathrm{~m} / \mathrm{v}+$ epoxiconazole $5 \% \mathrm{~m} / \mathrm{v}$ ) & $(500)$ & V6 \\
\hline & (fluxapyroxad $16.7 \% \mathrm{~m} / \mathrm{v}+$ pyraclostrobin $33.3 \% \mathrm{~m} / \mathrm{v})+($ mineral oil $75.6 \% \mathrm{~m} / \mathrm{v})$ & $(300)+(500)$ & R1 \\
\hline & (fluxapyroxad $16.7 \% \mathrm{~m} / \mathrm{v}+$ pyraclostrobin $33.3 \% \mathrm{~m} / \mathrm{v})+($ mineral oil $75.6 \% \mathrm{~m} / \mathrm{v})$ & $(300)+(500)$ & R5.1 \\
\hline & $($ pyraclostrobin $13 \% \mathrm{~m} / \mathrm{v}+$ metconazole $8 \% \mathrm{~m} / \mathrm{v})+($ mineral oil $75.6 \% \mathrm{~m} / \mathrm{v})$ & $(500)+(500)$ & R5.4 \\
\hline \multirow{4}{*}{10} & (fluxapyroxad $16.7 \% \mathrm{~m} / \mathrm{v}+$ pyraclostrobin $33.3 \% \mathrm{~m} / \mathrm{v})+($ mineral oil $75.6 \% \mathrm{~m} / \mathrm{v})$ & $(300)+(500)$ & V6 \\
\hline & $\begin{array}{l}\text { (pyraclostrobin } 80 \% \mathrm{~m} / \mathrm{v}+\text { fluxapyroxad } 16.7 \% \mathrm{~m} / \mathrm{v}+\text { epoxiconazole } 50 \% \mathrm{~m} / \mathrm{v})+ \\
(\mathrm{mineral} \text { oil } 75.6 \% \mathrm{~m} / \mathrm{v})\end{array}$ & $(800)+(500)$ & R1 \\
\hline & $\begin{array}{l}\text { (pyraclostrobin } 80 \% \mathrm{~m} / \mathrm{v} \text { + fluxapyroxad } 16.7 \% \mathrm{~m} / \mathrm{v}+\text { epoxiconazole } 50 \% \mathrm{~m} / \mathrm{v})+ \\
(\operatorname{mineral} \text { oil } 75.6 \% \mathrm{~m} / \mathrm{v})\end{array}$ & $(800)+(500)$ & R5.1 \\
\hline & $($ pyraclostrobin $13.3 \% \mathrm{~m} / \mathrm{v}+$ epoxiconazole $5 \% \mathrm{~m} / \mathrm{v})+($ mineral oil $75.6 \% \mathrm{~m} / \mathrm{v})$ & $(500)+(500)$ & R5.4 \\
\hline \multirow{4}{*}{11} & (pyraclostrobin $25 \% \mathrm{~m} / \mathrm{v})$ & $(300)$ & V6 \\
\hline & $\begin{array}{l}\text { (pyraclostrobin } 80 \% \mathrm{~m} / \mathrm{v}+\text { fluxapyroxad } 16.7 \% \mathrm{~m} / \mathrm{v}+\text { epoxiconazole } 50 \% \mathrm{~m} / \mathrm{v})+ \\
(\mathrm{mineral} \text { oil } 75.6 \% \mathrm{~m} / \mathrm{v})\end{array}$ & $(800)+(500)$ & R1 \\
\hline & $\begin{array}{l}(\text { pyraclostrobin } 80 \% \mathrm{~m} / \mathrm{v}+\text { fluxapyroxad } 16.7 \% \mathrm{~m} / \mathrm{v}+\text { epoxiconazole } 50 \% \mathrm{~m} / \mathrm{v})+ \\
(\operatorname{mineral} \text { oil } 75.6 \% \mathrm{~m} / \mathrm{v})\end{array}$ & $(800)+(500)$ & R5.1 \\
\hline & $($ pyraclostrobin $13.3 \% \mathrm{~m} / \mathrm{v}+$ epoxiconazole $5 \% \mathrm{~m} / \mathrm{v})+($ mineral oil $75.6 \% \mathrm{~m} / \mathrm{v})$ & $(500)+(500)$ & R5.4 \\
\hline \multirow{4}{*}{12} & (pyraclostrobin $13.3 \% \mathrm{~m} / \mathrm{v}+$ epoxiconazole $5 \% \mathrm{~m} / \mathrm{v})$ & $(500)$ & V6 \\
\hline & $\begin{array}{l}(\text { pyraclostrobin } 80 \% \mathrm{~m} / \mathrm{v}+\text { fluxapyroxad } 16.7 \% \mathrm{~m} / \mathrm{v}+\text { epoxiconazole } 50 \% \mathrm{~m} / \mathrm{v})+ \\
(\mathrm{mineral} \text { oil } 75.6 \% \mathrm{~m} / \mathrm{v})\end{array}$ & $(800)+(500)$ & $\mathrm{R} 1$ \\
\hline & $\begin{array}{l}(\text { pyraclostrobin } 80 \% \mathrm{~m} / \mathrm{v}+\text { fluxapyroxad } 16.7 \% \mathrm{~m} / \mathrm{v}+\text { epoxiconazole } 50 \% \mathrm{~m} / \mathrm{v})+ \\
(\mathrm{mineral} \text { oil } 75.6 \% \mathrm{~m} / \mathrm{v})\end{array}$ & $(800)+(500)$ & R5.1 \\
\hline & $($ pyraclostrobin $13.3 \% \mathrm{~m} / \mathrm{v}+$ epoxiconazole $5 \% \mathrm{~m} / \mathrm{v})+($ mineral oil $75.6 \% \mathrm{~m} / \mathrm{v})$ & $(500)+(500)$ & R5.4 \\
\hline
\end{tabular}

*mL of the commercial product or formulated product per hectare.

Four fungicide applications were performed, the first at January 16, 2013, at the phenological stage V6 (sixth node; fifth open trifoliate), the second at January 29, 2013, at the phenological stage R1 (beginning of flowering: $50 \%$ of plants with at least one flower), the third at February 13, 2013, at the phenological stage R5.1 (grains perceptible to touch at grain formation at $10 \%$ ), and the fourth at February 28, 2013, at the phenological stage R5.4 (most pods with grain formation of $50 \%$ to $75 \%$ ). The applications were scheduled with the first at the vegetative stage, the second at the flowering and the third and fourth at 15 and 30 days after flowering, respectively. The first application was performed as a preventive application in all treatments with fungicide. $\mathrm{A} \mathrm{CO}_{2}$-pressurized backpack sprayer was used for the applications, which had a three-meter- long bar and six spray nozzles type double fan TJ110.02, spaced at $50 \mathrm{~cm}$.

The solution volume used was $150 \mathrm{~L} \mathrm{ha}^{-1}$, with a spray pressure of $30 \mathrm{psi}$. Weather conditions were monitored by a meteorological station located approximately 500 meters from the experimental area during the experiment. The weather conditions were monitored with a portable weather station (Kestrel 3000), positioned at the same height of the top of the plants during applications. The temperature, relative humidity and maximum wind speed were evaluated at the start and end of applications (Table 2). According to Hoffman (2004), the most suitable weather conditions for spraying are temperature below $30^{\circ} \mathrm{C}$, relative humidity above $55 \%$ and wind speed below $10 \mathrm{~km} \mathrm{~h}^{-}$ 1 .

Table 2. Weather conditions during the fungicide applications.

\begin{tabular}{lcccccccc}
\hline \multicolumn{1}{c}{ Applications } & \multicolumn{2}{c}{ V6 } & \multicolumn{2}{c}{ R1 } & R5.1 & \multicolumn{2}{c}{ R5.4 } \\
\hline & Start & End & Start & End & Start & End & Start & End \\
\hline Time $(\mathrm{h})$ & $17: 20$ & $17: 55$ & $10: 35$ & $11: 10$ & $09: 10$ & $09: 36$ & $16: 40$ & $17: 05$ \\
Temperature $\left({ }^{\circ} \mathrm{C}\right)$ & 29.2 & 28.7 & 28.2 & 28.0 & 28.7 & 29.2 & 30.0 & 28.7 \\
Relative humidity $(\%)$ & 65.9 & 66.4 & 66.9 & 72.3 & 69.9 & 70.0 & 64.3 & 68.7 \\
Wind max. speed $\left(\mathrm{km} \mathrm{h}^{-1}\right)$ & 2.5 & 1.8 & 9.3 & 8.4 & 1.7 & 2.3 & 3.1 & 2.3 \\
Cloudiness $(\%)$ & 40 & 60 & 50 & 55 & 05 & 05 & 40 & 50 \\
\hline
\end{tabular}

The efficacy of the products was assessed regarding the disease severity (percentage of injury in the leaf area, which is calculated under the disease progress curve - AUDPC), relative effectiveness, phytotoxicity, defoliation, yield and relative increase in crop yield.
The percentage of injury in the leaf area was evaluated in two parts of the plants (upper and lower) though the diagrammatic scale proposed by Canteri and Godoy (2003), using five plants per plot, which were randomly sampled. Evaluations were performed in January 16, 2013, at the phenological 
stages V6 (sixth node; fifth open trifoliate), in February 18, 2013, at R5.2 (most pods with grain formation of 10 to $25 \%$ ), in February 28, 2013, at R5.4 (most with grain formation of 50 and $75 \%$ ) and in March 10, 2013, at R6 (pods with grain formation of $100 \%$ and green leaves), totaling four evaluations.

The evaluated trifoliates were from the same height in all plants and treatments. The number of nodes of the plants were counted and, for the bottom half, the third trifoliate from the bottom was evaluated, while for the upper half, the second trifoliate from top was evaluated. The first trifoliate from the bottom was evaluated along the defoliation in the lower third, which was performed in the Control treatment. The average severity data was used to calculate the AUDPC, as proposed by Shaner and Finney (1977).

The relative efficacy values of fungicides considered the AUDPC value with the Control being $100 \%$, then, the proportional control percentage was calculated for each treatment, so the value found in each treatment was subtracted from 100 . The result was the value of relative efficacy for each treatment.

The selectivity of the fungicides was evaluated through visual analysis of symptomatic plants (phytotoxicity) after each application, following descriptive and diagrammatic scales proposed by Campos and Silva (2012), where $0=$ no phytotoxicity, 1 = very light: up to $10 \%$ of the leaf area with presence of chlorosis or bronzing, $2=$ moderately light: $11-25 \%$ of leaf area with chlorosis or bronzing, $3=$ light: $11-25 \%$ of the leaf area affected and with necrosis, $4=$ moderately strong: 25 $-50 \%$ of the leaf area affected and with necrosis, $5=$ strong: $50-75 \%$ of the leaf area affected and with pronounced necrosis, $6=$ very strong: more than $75 \%$ of the leaf area affected and with pronounced necrosis, 7 = extremely strong: total dry of the affected leaflet.

Three evaluations were performed after each fungicide application. The defoliation evaluation was performed in R7 (50\% yellowing of leaves and pods), based on visual defoliation percentage. The crop yield was evaluated by the plot harvest and the thousand grain weight was calculated. The grain moisture was adjusted to $13 \%$. The relative increase in yield was calculated by comparing to the Control, considering the Control yield as $100 \%$.

A randomized block experimental design was used, with twelve treatments and four replications.

Data were subjected to analysis of variance and the Scott-Knott test at 5\% probability, using the software SISVAR 4.0 (FERREIRA, 2000).

\section{RESULTS AND DISCUSSION}

The results of all treatments with fungicides were different from the Control, confirming the affirmation of Dal Pogetto (2012), which says that a single fungicide spraying, regardless of crop phenological stage, is sufficient to promote a significantly higher yield compared to the Control.

The first severity evaluation, performed in V6, presented no incidence of soybean rust. The other evaluations, performed at the phenological stages R5.2, R5.4 and R6, presented disease progression in the Control, with medium severity (37\%) during the last evaluation.

The use of fungicides must be planned according to the risk factors that are monitored during the crop season, and the application and reapplication at the right time has fundamental importance in controlling the disease and ensure higher profits for producers (GODOY et al., 2009), considering the second, third and fourth severity evaluations based on AUDPC.

The treatments that received two applications of pyraclostrobin + fluxapyroxad associated with pyraclostrobin + metconazole or pyraclostrobin + fluxapyroxad + epoxiconazole and those that received two applications of pyraclostrobin + fluxapyroxad + epoxiconazole (Table 4) presented greater efficacy on the disease control.

The application of triazole + strobilurin presents greater control of Asian rust compared to these fungicides applied singly (GARCÉSFIALLOS; FORCELINI, 2013). The results of cooperative assays also confirm this fact. For example, in the $2008 / 2009$ crop season, triazoles presented $34-49 \%$ of control, while mixtures presented 63-73\% (GODOY et al. 2009). Similar results were also found in cooperative assays in the subsequent crops (2009/2010, 2010/2011 and 2011/2012) (GODOY et al., 2010; GODOY et al., 2011; GODOY et al., 2012). Regarding triple mixtures, applications with the fungicide pyraclostrobin + epoxiconazole + fluxapyroxad presented more efficacy compared to the standard fungicides (triazole + strobilurin) only at the tenth trifoliate period, due to higher absorption of fungicide by the upper leaflets and increasing of the number of action sites on the pathogen (AUGUSTINE et al., 2014).

The carboxamides has presented a wide control diversity for soybean fungi, and the fluxapyroxad, within this chemical group, is presenting efficacy in controlling the soybean rust, as shown in this study. Wei, Teramoto et al. (2012) found also satisfactory results using fluxapyroxad in Corynespora cassicola (BERK; CURT.).

The relative efficacy of fungicides compared to the Control ranged from $76.94 \%$ (epoxiconazole + pyraclostrobin + mineral oil at the phenological stages V6, R1, R5.1 and R5.4), to 98.04\% (pyraclostrobin + fluxapyroxad + mineral oil at V6, pyraclostrobin + fluxapyroxad + epoxiconazole + mineral oil at R1 and R5.1 and epoxiconazole + pyraclostrobin + mineral oil at R5.4) (Table 3). The reduction in symptoms associated with lower 
viability of urediniospores after application of fungicides can slow the disease progress (GODOY; CANTERI, 2004).

The serial application of pyraclostrobin and epoxiconazole (treatment 3) presented less efficacy compared to other treatments. The fungicide application programs that have presented the best efficacy were the T9 (pyraclostrobin + epoxiconazole at V6, pyraclostrobin + fluxapyroxad at R1 and R5.1 and pyraclostrobin + metconazole at R5.4), T10 (pyraclostrobin + fluxapyroxad at V6, pyraclostrobin + fluxapyroxad + epoxiconazole at R1 and R5.1 and pyraclostrobin + epoxiconazole at
R5.4), T11 (pyraclostrobin at V6, pyraclostrobin + fluxapyroxad + epoxiconazole at R1 and R5.1 and pyraclostrobin + epoxiconazole at R5.4), T12 (pyraclostrobin + epoxiconazole at V6, pyraclostrobin + fluxapyroxad + epoxiconazole at R1 and R5.1 and pyraclostrobin + epoxiconazole at R5.4). The fungicide applications performed close to the $P$. pachyrhizi infection time in the soybean plants and with fungicides with active ingredients with distinct mechanism of action, were more effective in controlling the soybean rust (MENEGHETTI et al., 2010).

Table 3. Area under the disease progress curve (AUDPC), relative efficacy (\%), phytotoxicity (\%) and defoliation (\%) with chemical control of Asian soybean rust.

\begin{tabular}{|c|c|c|c|c|}
\hline Treatments & $\begin{array}{l}\text { AUDPC } \\
\text { (average) }\end{array}$ & $\begin{array}{c}\text { Relative } \\
\text { Efficacy } \\
(\%) \\
\end{array}$ & Phytotoxicity (\%) & $\begin{array}{c}\text { Defoliation } \\
(\%)\end{array}$ \\
\hline 1 Control & $399.79 \mathrm{~g}$ & - & 0 & $80.75 \mathrm{~d}$ \\
\hline $\begin{array}{l}2 \text { piracl. } \\
\text { piracl.+ epox.+ oil }\end{array}$ & $80.02 \mathrm{e}$ & 79.98 & 0 & $50.00 \mathrm{c}$ \\
\hline 3 piracl. + epox. + oil & $92.20 \mathrm{f}$ & 76.94 & 0 & $52.50 \mathrm{c}$ \\
\hline $\begin{array}{l}4 \text { piracl. } \\
\text { piracl.+ flux. }+ \text { oil } \\
\text { piracl.+ epox.+ oil }\end{array}$ & $36.02 \mathrm{~d}$ & 90.99 & 0 & $40.00 \mathrm{~b}$ \\
\hline $\begin{array}{l}5 \text { piracl.+ epox. } \\
\text { piracl.+ flux. }+ \text { oil } \\
\text { piracl.+ epox.+ oil }\end{array}$ & $37.81 \mathrm{~d}$ & 90.54 & 0 & $37.50 \mathrm{~b}$ \\
\hline $\begin{array}{l}6 \text { piracl. } \\
\text { piracl. }+ \text { flux. }+ \text { oil } \\
\text { piracl. }+ \text { epox. }+ \text { oil }\end{array}$ & $26.76 \mathrm{c}$ & 93.31 & 1 & $32.50 \mathrm{~b}$ \\
\hline $\begin{array}{l}7 \text { piracl.+ epox. } \\
\text { piracl.+ flux. }+ \text { oil } \\
\text { piracl.+ epox.+ oil }\end{array}$ & $16.94 \mathrm{~b}$ & 95.76 & 1 & $33.75 \mathrm{~b}$ \\
\hline $\begin{array}{l}8 \text { piracl. } \\
\text { piracl. }+ \text { flux. }+ \text { oil } \\
\text { piracl. }+ \text { metc. }+ \text { oil } \\
\end{array}$ & $16.22 \mathrm{~b}$ & 95.94 & 2 & $30.00 \mathrm{a}$ \\
\hline $\begin{array}{l}9 \text { piracl.+ epox. } \\
\text { piracl.+ flux. }+ \text { oil } \\
\text { piracl. }+ \text { metc. }+ \text { oil }\end{array}$ & $11.21 \mathrm{a}$ & 97.20 & 1 & $36.25 \mathrm{~b}$ \\
\hline $\begin{array}{l}10 \text { piracl.+ flux. + oil } \\
\text { piracl. + flux. }+ \text { epox. }+ \text { oil } \\
\text { piracl.+ epox. }+ \text { oil }\end{array}$ & $7.85 \mathrm{a}$ & 98.04 & 1 & $25.00 \mathrm{a}$ \\
\hline $\begin{array}{l}11 \text { piracl. } \\
\text { piracl. }+ \text { flux. }+ \text { epox. }+ \text { oil } \\
\text { piracl.+ epox. }+ \text { oil }\end{array}$ & $11.44 \mathrm{a}$ & 97.14 & 1 & $30.00 \mathrm{a}$ \\
\hline $\begin{array}{l}12 \text { piracl.+ epox. } \\
\text { piracl. }+ \text { flux. }+ \text { epox. }+ \text { oil } \\
\text { piracl.+ epox. }+ \text { oil }\end{array}$ & $8.15 \mathrm{a}$ & 97.96 & 1 & $27.50 \mathrm{a}$ \\
\hline CV (\%) & 6.62 & & & 11.49 \\
\hline
\end{tabular}

Averages followed by the same letter in the same column do not differ by the Scott Knott test at $5 \%$ probability. piracl. = pyraclostrobin; epoxy. $=$ epoxiconazole; flux. $=$ fluxapyroxad; metc. $=$ metconazole; oil $=$ mineral oil.

Regarding the phytotoxicity, mild symptoms were observed, with up to $10 \%$ of the leaf area with chlorosis or bronzing in the treatments that had two applications of pyraclostrobin + fluxapyroxad or pyraclostrobin + fluxapyroxad + epoxiconazole with mineral oil. The maximum phytotoxicity, with 11 and $25 \%$ of leaf area with chlorosis or bronzing, was observed in the application containing epoxiconazole + pyraclostrobin, pyraclostrobin + fluxapyroxad + mineral oil, pyraclostrobin + metconazole.

According to the defoliation evaluation performed at the phenological stage R7, all treatments with fungicide application differed from the Control, which presented $80.75 \%$ defoliation. 
The defoliation in the treatments with fungicides ranged from $25 \%$ in treatment 10 (fluxapyroxad + pyraclostrobin + mineral oil, pyraclostrobin + fluxapyroxad + epoxiconazole + mineral oil, epoxiconazole + pyraclostrobin + mineral oil) to $52.50 \%$ (epoxiconazole + pyraclostrobin + mineral oil) in treatment 3 (Table 3 ). A high defoliation rate presented in the Control was also observed by Golden Neto et al. (2007), which reached 77.5\%, resulting in a low crop yield. Reis et al. (2007) found low defoliation and significant increase in soybean yield in treatments with the active ingredients tetraconazole and pyraclostrobin + epoxiconazole in the first applications, under a situation of high disease severity, in R1.

The thousand grain weight and yield of treatments with fungicides were higher compared to the Control (Table 4). The treatments 2 and 3 presented no statistical difference regarding the thousand grain weight and yield, the difference between these two treatments was the fungicide applied at V6, with pyraclostrobin in treatment 2, and pyraclostrobin + epoxiconazole + mineral oil in treatment 3; the other applications, at R1, R5.1 and R5.4 were with pyraclostrobin + epoxiconazole + mineral oil in both treatments.

Regarding the thousand grain weight, treatments 4, 5, 6 and 8 presented no difference, however had results better than the treatment 2 and 3. Treatments 4, 6 and 8 had pyraclostrobin at V6, while treatment 5 had pyraclostrobin + epoxiconazole. Fluxapyroxad + pyraclostrobin + mineral oil were applied at R1 in treatments 4, 5, 6 and 8 and at R5.1 in treatments 6 and 8 . Pyraclostrobin + epoxiconazole were applied at R5.1 in treatments 4 and 5 and at R5.4 in treatments 4, 5, 6. Pyraclostrobin + metconazole were applied at R5.4 in treatment 8 .

Table 4. Thousand grain weight (TGW), yield and relative yield increase due to the chemical control of soybean rust.

\begin{tabular}{|c|c|c|c|c|}
\hline Treatments & TGW (g) & $\begin{array}{l}\text { Yield } \\
\left(\mathrm{kg} \mathrm{ha}^{-1}\right)\end{array}$ & \multicolumn{2}{|c|}{ Relative yield increase } \\
\hline 1 Control & $114.22 \mathrm{e}$ & $2,568.07 \mathrm{c}$ & & \\
\hline $\begin{array}{l}2 \text { piracl. } \\
\text { piracl. }+ \text { epox. }+ \text { oil }\end{array}$ & $127.54 \mathrm{~d}$ & $2,826.11 \mathrm{~b}$ & 258.04 & 4.30 \\
\hline 3 piracl. + epox. + oil & $128.88 \mathrm{~d}$ & $2,887.32 \mathrm{~b}$ & 319.25 & 5.32 \\
\hline $\begin{array}{l}4 \text { piracl. } \\
\text { piracl. }+ \text { flux. }+ \text { oil } \\
\text { piracl. }+ \text { epox. }+ \text { oil }\end{array}$ & $132.63 \mathrm{c}$ & $3,218.50 \mathrm{a}$ & 650.43 & 10.84 \\
\hline $\begin{array}{l}5 \text { piracl. + epox. } \\
\text { piracl. }+ \text { flux. }+ \text { oil } \\
\text { piracl. }+ \text { epox. }+ \text { oil }\end{array}$ & $129.79 \mathrm{c}$ & $3,029.23 \mathrm{a}$ & 461.16 & 7.69 \\
\hline $\begin{array}{l}6 \text { piracl. } \\
\text { piracl. }+ \text { flux. }+ \text { oil } \\
\text { piracl. }+ \text { epox. }+ \text { oil }\end{array}$ & $129.40 \mathrm{c}$ & $3,109.86 \mathrm{a}$ & 541.79 & 9.03 \\
\hline $\begin{array}{l}7 \text { piracl. + epox. } \\
\text { piracl. + flux. }+ \text { oil } \\
\text { piracl. }+ \text { epox. }+ \text { oil } \\
\end{array}$ & $135.94 \mathrm{~b}$ & $3,116.55 \mathrm{a}$ & 548.48 & 9.14 \\
\hline $\begin{array}{l}8 \text { piracl. } \\
\text { piracl. }+ \text { flux. }+ \text { oil } \\
\text { piracl. }+ \text { metc. }+ \text { oil }\end{array}$ & $132.56 \mathrm{c}$ & $3,352.68 \mathrm{a}$ & 784.61 & 13.08 \\
\hline $\begin{array}{l}9 \text { piracl. + epox. } \\
\text { piracl. + flux. }+ \text { oil } \\
\text { piracl. }+ \text { metc. }+ \text { oil } \\
\end{array}$ & $135.16 \mathrm{~b}$ & $3,189.41 \mathrm{a}$ & 571.49 & 9.52 \\
\hline $\begin{array}{l}10 \text { piracl. + flux. + oil } \\
\text { piracl. + flux. + epox. + oil } \\
\text { piracl. + epox. + oil }\end{array}$ & $140.92 \mathrm{a}$ & $3,139.56 \mathrm{a}$ & 571.49 & 9.52 \\
\hline $\begin{array}{l}11 \text { piracl. } \\
\text { piracl. + flux. + epox. + oil } \\
\text { piracl. + epox. + oil }\end{array}$ & $139.30 \mathrm{a}$ & $2,954.23 \mathrm{~b}$ & 386.16 & 6.44 \\
\hline $\begin{array}{l}12 \text { piracl. + epox. } \\
\text { piracl. + flux. + epox. }+ \text { oil } \\
\text { piracl. + epox. + oil }\end{array}$ & $140.87 \mathrm{a}$ & $3,147.39 \mathrm{a}$ & 579.32 & 9.66 \\
\hline CV $(\%)$ & 1.99 & 10.50 & & \\
\hline
\end{tabular}

Averages followed by the same letter in the same column do not differ by the Scott Knott test at $5 \%$ probability. piracl. = pyraclostrobin; epoxy. = epoxiconazole; flux. = fluxapyroxad; metc. = metconazole; oil = mineral oil. 
Treatments 7 and 9 presented no difference regarding the thousand grain weight, however had better performance compared to the treatments 2,3 , 4, 5, 6 and 8, which had fungicide applications at V6 with pyraclostrobin + epoxiconazole, and at R1 and R5.1 with fluxapyroxad + pyraclostrobin + mineral oil, while the treatment 7 had pyraclostrobin + epoxiconazole + mineral oil at R5.4, and treatment 9 had pyraclostrobin + metconazole + mineral oil at R5.4.

The treatments 10, 11 and 12 had higher thousand grain weights compared to other treatments. The applications at V6 in these treatments were fluxapyroxad + pyraclostrobin + mineral oil in treatment 10 , pyraclostrobin in treatment 11, pyraclostrobin + epoxiconazole in treatment 12; the applications at R1 and R5.1 were pyraclostrobin + fluxapyroxad + epoxiconazole + mineral oil and at R5.4 was pyraclostrobin + epoxiconazole + mineral oil, in the treatments 10,11 , 12. The treatment 10 had thousand grain weight of $140.92 \mathrm{~g}$, while the Control had $114.22 \mathrm{~g}$.

The yields of all treatments with fungicide application were higher than the Control (Table 4), confirming the results found by Soares (2004). The treatments had values ranging from $2826 \mathrm{~kg} \mathrm{ha}^{-1}$ (treatment 2; pyraclostrobin at V6 and epoxiconazole + pyraclostrobin + mineral oil at R1, R5.1 and R5.4) to $3353 \mathrm{~kg} \mathrm{ha}^{-1}$ (treatment 8; pyraclostrobin at V6, pyraclostrobin + fluxapyroxad + mineral oil at R1 and R5.1, pyraclostrobin + metconazole + mineral oil at R5.4), while the Control had $2568 \mathrm{~kg} \mathrm{ha}^{-1}$ (Table 4). Lima et al. (2010) applied pyraclostrobin and metconazole for controlling the angular leaf spot and anthracnose in common bean, and found higher grain yield, reaching $22 \%$ of increase.

\section{CONCLUSIONS}

The treatments 9 (pyraclostrobin + epoxiconazole at V6, pyraclostrobin + fluxapyroxad at R1 and R5.1 and pyraclostrobin + metconazole at R5.4), 10 (pyraclostrobin + fluxapyroxad at V6, pyraclostrobin + epoxiconazole + fluxapyroxad at R1 and R5.1 and pyraclostrobin + epoxiconazole at R5.4) 11 (pyraclostrobin at V6, pyraclostrobin + epoxiconazole + fluxapyroxad at R1 and R5.1 and pyraclostrobin + epoxiconazole at R5.4) and 12 (pyraclostrobin + epoxiconazole at V6, pyraclostrobin + epoxiconazole + fluxapyroxad at R1 and R5.1 pyraclostrobin + epoxiconazole at R5.4) provided the greatest rates of soybean rust control.

The treatments 10 (pyraclostrobin + fluxapyroxad at V6, pyraclostrobin + epoxiconazole + fluxapyroxad at R1 and R5.1 and pyraclostrobin + epoxiconazole at R5.4) 11 (pyraclostrobin at V6, pyraclostrobin + epoxiconazole + fluxapyroxad at R1 and R5.1 and pyraclostrobin + epoxiconazole at R5.4) and 12 (pyraclostrobin + epoxiconazole at V6, pyraclostrobin + epoxiconazole + fluxapyroxad at R1 and R5.1 pyraclostrobin + epoxiconazole at R5.4), had the highest thousand grain weights.

The chemical control increased the grain yield, especially with the treatment 8 (pyraclostrobin at V6, fluxapyroxad + pyraclostrobin at R1 and fluxapyroxad + pyraclostrobin at R5.1 and pyraclostrobin + metconazole at R5.4), which provided an increase of $784,8 \mathrm{~kg} \mathrm{ha}^{-1}$, compared to the Control without fungicide.

\section{REFERENCES}

AUGUSTI, G. R. et al. Aplicações preventivas e erradicantes de fungicidas no controle da ferrugem asiática da soja. Summa Phytopathol, Botucatu, v. 40, n. 3, p. 288-289, 2014.

BARBOSA, G. F.; CENTURION, M. A. P. C.; FERRAUDO, A. S. Potencial do manejo integrado da ferrugem asiática da soja: severidade da doença, desenvolvimento vegetativo e componentes da produção, cultivar mg/br-46 (conquista). Bioscience Journal, Uberlândia, v. 30, n. 1, p. 76-89, 2014.

BONDE, M. R. et al. Effects of temperature on urediniospore germination germ tube growth, and initiation of infection in soybean by Phakopsora isolates. Phytopathology, Saint Paul, v. 97, n. 8, p. 997-1003, 2007.

CAMPOS, H. D; SILVA, L. H. C. P. Escalas descritiva e diagramática para avaliação de fitotoxidez em função da intensidade de cloroses e/ou bronzeamentos e necroses foliares causadas por fungicidas. Rio Verde, GO: UniRV, 2012, 2 p.

CANTERI, M.; GODOY, C. V. Escala diagramática da ferrugem da soja (Phakopsorapachyrhizi). Summa Phytopathologica, Botucatu, v. 2, n. 14, p. 32-33, 2003.

COMPANHIA NACIONAL DE ABASTECIMENTO. ACOMPANHAMENTO DE SAFRA BRASILEIRA, (CONAB): grãos, décimo segundo levantamento, setembro 2014. Brasília, DF, 2014. Disponível em: <http:// www.conab.gov.br/OllalaCMS/uploads/

arquivos/14_09_10_14_35_0_boletim graos setemb ro_2014.pdf. $>$. Acesso em: $1 \overline{6}$ set.2014.

CUNHA, J. P. A. R.; JULIATTI, F. C.; REIS, E. F. Tecnologia de aplicação de fungicida no controle da ferrugem asiática da soja: resultados de oito anos de estudos em minas gerais e goiás. Bioscience Journal, Uberlândia, v. 30, n. 4, p. 950-957, 2014.

DAL POGETTO, M. H. F. A. et al. Controle da ferrugem asiática e produtividade da soja após 
pulverizações de piraclostrobina + epoxiconazole em diferentes estádios fenológicos da cultura. Summa Phytopathologica, Botucatu, v. 38, n. 3, p. 248-250, 2012.

DOURADO NETO, D. et al. Controle químico da ferrugem asiática na cultura da soja em condições de campo. Revista da FZVA, Uruguaiana, v. 14, n. 1, p. 69-80. 2007.

EMBRAPA. Reunião de Pesquisa de Soja para a Região Central do Brasil. Londrina, PR: Embrapa Soja, 2006. 173 p.

FERREIRA, D. F. Análise estatísticas por meio do SisVar para windows versão 4.0. In: REUNIÃO ANUAL DA REGIÃO BRASILEIRA DA SOCIEDADE INTERNACIONAL DE BIOMETRIA, 45., 2000, São Carlos. Anais... São Carlos: UFS Car, 2000. p. 255-258.

FURLAN, S. H. Impacto, diagnose e manejo da ferrugem asiática da soja no Brasil. 2013. Disponível em: <http:www.biologico.sp.gov.br/rifib/ XI RIFIB/furlan.PDF>. Acesso em 17/06/2013.

GARCÉS-FIALHOS, F. R.; FORCELINI, C. A. Controle comparativo da ferrugem asiática da soja com fungicida triazol ou mistura de triazol + estrobilurina. Bioscience Journal, Uberlândia, v. 29, n. 4, p. 805-815, July/Aug. 2013.

GARCÉS-FIALHOS, F. R. A ferrugem asiática da soja causador por Phakopsora pachyrhiziSydow e Sydow. Ciência Y Tecnologia, Misiones, v. 2, n. 4, p. 45-60, 2011.

GODOY, C. V.; CANTERI, M. G. Efeitos protetor, curativo e erradicante de fungicidas no controle da ferrugem da soja causada por Phakopsora pachyrhizi, em casa de vegetação. Fitopatologia Brasileira, Brasília, v 29, n. 1, p 97-101. 2004.

GODOY, C. V. et al. M. Eficiência do controle da ferrugem asiática da soja em função do momento de aplicação sob condições de epidemia em Londrina, PR. Tropical Plant Pathology, Viçosa, v. 34, n. 1, p 56-61, 2009.

GODOY, C. V. et al. Eficiência de fungicidas para controle da ferrugem asiática da soja, Phakopsora pachyrhizi, na safra 2009/10: resultado sumarizados dos ensaios cooperativos. Londrina-PR: Embrapa, 2010. 8 p. (Embrapa. Circular Técnica, 80).

GODOY, C. V. et al. Eficiência de fungicidas para controle da ferrugem asiática da soja, Phakopsora pachyrhizi, na safra 2010/11: resultado sumarizados dos ensaios cooperativos. Londrina-PR: Embrapa, 2011. 8 p. (Embrapa. Circular Técnica, 87).
GODOY, C. V. et al. Eficiência de fungicidas para o controle da ferrugem-asiática da soja, Phakopsora pachyrhizi, na safra 2011/12: resultados sumarizados dos ensaios cooperativos. Londrina: Embrapa, 2012. (Embrapa. Circular Técnica, 93). Cerrado Agrociências. Patos de Minas- MG.: UNIPAM, (1): 54-59, ago. 2010.

HOFFMANN, L. L.; BOLLER, W. Tecnologia de aplicação de fungicidas em soja. In: REIS, E. M. Doenças na cultura da soja. Aldeia Norte Editora, Passo Fundo, p. 147-170, 2004.

IGARASHI, et al. Duração e porcentagem de molhamento foliar determinados pelo espaçamento entrelinhas, e influência sobre a ferrugem asiática da soja. Summa phytopathol, Botucatu, v. 40, n. 2, p. $123-127,2014$

LEVY, C. Epidemiology and chemical control of soybean rust in southern Africa. Plant Disease, Saint Paul, v. 89, n. 6, p. 669-674, 2005.

LIMA, P. R. A. et al. Eficiência de fungicidas no controle da antracnose e da mancha angular do feijoeiro comum. Cerrado Agrociências, Patos de Minas, v 1, n. 1, p 54-59, 2010.

MAGNANI, E. B. Z.; ALVES, E.; ARAÚJO, D. V. Eventos dos processos de pré-penetração, penetração e colonização de Phakopsorapachyrhizi em folíolos de soja. Fitopatologia Brasileira, Brasília, v 32, n. 2, p 156-160. 2007.

MENEGHETTI, R. C. et al. Avaliacao da ativação de defesa em soja contra Phakopsora pachyrhizi em condições controladas. Ciência \& Agrotecnologia, Lavras, v. 34, n. 4, p. 823-829, 2010.

MENEGON, A. P.; FORCELINI, C. A.; FERNANDES, J. M. C. Expansão de lesão da mancha-reticular da cevada e sua interação com o tratamento de sementes. Fitopatologia Brasileira, Brasília, v. 30, n. 2, p 139-142. 2005.

PINTO, T. L. F. et al. Fungicidas foliares e a doença ferrugem asiática na produção e na qualidade de sementes de soja. Revista brasileira sementes, Londrina, v. 33, n. 4, p. 680-688. 2011.

REIS, E. F. et al. Controle químico da ferrugem asiática da soja na região sul do paraná. Scientia Agraria, Curitiba, v. 8, n. 3, p. 319-323, 2007.

SHANER, G.; FINNEY, R. E. The effect of nitrogen fertilization on the expression of slow-mildewing resistance in knox wheat. Phytopathology, Saint Paul, v. 67, n. 8, p. 1051-1056, 1977.

SOARES, R. M. et al. Fungicidas no controle da 
ferrugem asiática (Phakopsora pachyrhizi) e produtividade da soja. Ciência Rural, Santa Maria, v. 34, n. 4, p. 1245-1247, 2004.

TERAMOTO, A. et al, M.G. Sensibilidade a fungicidas de isolados de Corynespora cassiicola provenientes do estado de Goiás. Congresso Brasileiro de Soja, 6... 2012. Cuiabá - MT. Anais...Cuiabá-MT: Embrapa Soja, 2012. p. 24-28.

YORINORI, J. T. et al. Epidemics of soybean rust (Phakopsora pachyrhizi) in Brazil and Paraguay from 2001 to 2003. Plant Disease, Saint Paul, v. 89, n. 4, p. 675-677, 2005. 